\title{
Mitigation Plan for Identified Problems Faced by the Marble Industry in Khyber Pakhtunkhwa
}

\author{
Salim Raza $^{1 *}$, Khan Gul Jadoon ${ }^{2}$, Sajjad Hussain ${ }^{1}$, Zahid ur Rehman $^{1}$, Saira Sherin ${ }^{1}$ and Noor Muhammad ${ }^{1}$ \\ ${ }^{1}$ Department of Mining Engineering, UET Peshawar, Khyber Pakhtunkbwa, Pakistan; ${ }^{2}$ Balochistan University of Information \\ Technology, Engineering and Management Sciences, Quetta, Pakistan
}

\begin{abstract}
Marble is one of the important dimension stones used for verity of purposes including exterior and interior decoration of buildings. Leading countries in the production and export of marble including China, Italy, India, Spain, Brazil and US etc., have developed their marble sectors on scientific grounds by applying modern techniques. Pakistan also hosts huge reserves of different qualities of marble but this sector could not developed to the international standards due to a number of difficulties. As a result of these problems, the raw marble excavated from quarries carries less economic value and could not compete in the international market. Marble industry of Khyber Pakhtunkhwa is selected for this study because major activities in this sector are being carried out in this province where more than $90 \%$ of the country's reserves are located. The research documented here highlights and evaluates different problems faced by the marble industry in Khyber Pakhtunkhwa (KP), Pakistan and mitigation plan is proposed to overcome these problems with the aim to develop the marble mining sector for improved product quality and subsequent processing for efficient mining and export of marble according to international standards.

Received: January 11, 2020; Accepted: May 23, 2020; Published: June 22, 2020

*Correspondence: Salim Raza, Department of Mining Engineering, UET Peshawar, Khyber Pakhtunkhwa, Pakistan; Email: raza@uetpeshawar. edu.pk

Citation: Raza, S., S. Hussain, K.G. Jadoon, Z.u. Rehman, S. Sherin and N. Muhammad. 2020. Mitigation plan for identified problems faced by the marble industry in Khyber Pakhtunkhwa. Journal of Engineering and Applied Sciences, 39(1): 77-86.

DOI: http://dx.doi.org/10.17582/journal.jeas/39.1.77.86

Keywords: Marble sector; Problems; Mitigation Plan
\end{abstract}

\section{Introduction}

$\mathrm{T}$ The dimension stone industry of Pakistan has potential to impart in uplifting the national Gross Domestic Product (GDP) and produce new opportunities. Due to their attractive appearance and durability, trend in the use of dimension stones is increasing rapidly. The annual increase in use of dimension stone in Pakistan was 6.45\% in 1997 which is estimated to grow up to $7.73 \%$ in 2025 with an average annual increase of 6.86\% (GDM Stone Industries Handbook, 2000). According to an estimate, the world's annual stone production was over 60 million tones with an increase of 5\% per year (Rathore et al., 2003) whereas the granite and marble stone production was increased by $12 \%$ in 2014 than its production in 2013. The top five producing countries of dimension stone are China, India, Turkey, Iran, and Italy and contributed about $74 \%$ of the world's production (U.S. Geological Survey, 2018). Since 1998 till now, China is leading the dimension stone world by sharing $17.87 \%$ of the world's production. Italy's share is $10.63 \%$, Germany $7.55 \%$ and India $5.75 \%$ (Figure 1). Pakistan shares less than $0.50 \%$ in the world marble production with an average of 497,317 metric tons per year (Ashmole and Motloung, 2008; GSP Report, 2004), which is not significant and needs to be improved. 


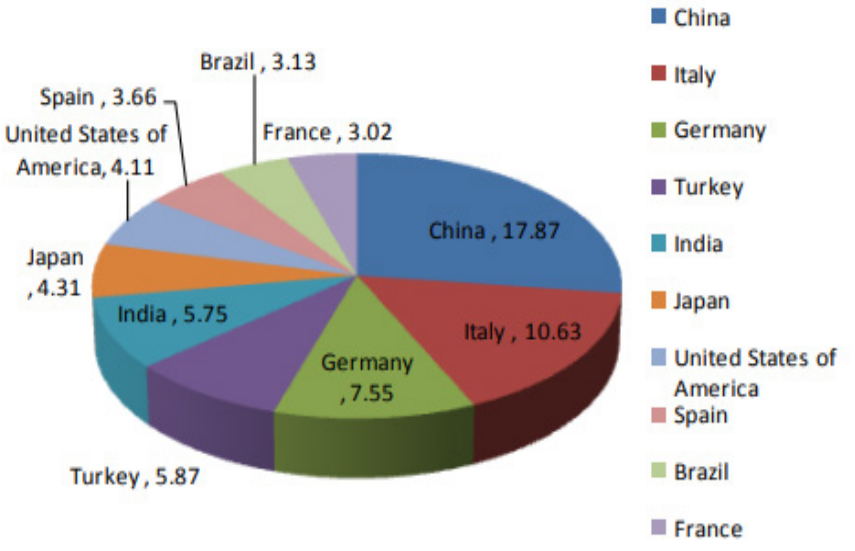

Figure 1: Dimension stone production of the world (Rehman et al., 2018).

Pakistan has approximately 292.2 billion tonnes indicated marble reserves among these $99 \%$ exist in Khyber Pakhtunkhwa (KP). The province of Khyber Pakhtunkhwa annually produces about $87 \%$ Marble, $1 \%$ Granite and 12\% slate (Khan, 2017; Rehman et al. 2018). Dimension stone reserves of Pakistan are available in a wide range of colors, shades, and patterns. According to DGMM Khyber Pakhtunkhwa (2004), these deposits include marble, granite, limestone, onyx, sandstone and slate. Based on the colors of the different colored marble available in Pakistan are presented in Table 1 (Ashmole and Motloung, 2008), which shows beautiful combination of colors. Since dimension stones are mostly used for decoration purposes, therefore their demand increases day by day. Besides decoration stone, it can also be used for construction purposes such as flooring, kitchens countertops, bathrooms tiles, shower walls, columns, memorials, stone handicrafts, tabletops and novelties (Ashmole and Motloung, 2008; Merke, 2000).

Although Pakistan has huge reserves of beautiful colors of dimension stone, but the industry has not developed yet due to several problems that the industry faces. In the research documented here different problems faced by the marble industries of Khyber Pakhtunkhwa are highlighted and mitigation plan is proposed to overcome these difficulties with the aim to develop the marble mining industry of the country by improving its quality as per international standards.

\section{Marble sector of Khyber Pakbtunkhwa}

As discussed earlier, the province of Khyber Pakhtunkhwa hosts major marble reserves of the country i.e., 2,900 million tons which is about $99 \%$ of the country's reserves Khan (2017), GSP (2017) and DGMM NWFP and SDA (2004). The total marble bearing areas of KP are divided into four belts (Table 2 ).

Major marble mining areas include Buner, Mardan, Swabi, Nowshera, Mansehra, Malakand and Chitral districts. Among these, one of the best quality marble reserves in the country is located near Bampokha village in district Buner (SDA, 2017). Besides above localities, substantial reserves of good quality marble are found in the ex-FATA areas Khyber Pakhtunkhwa i.e, Khyber, Mohmand and Bajaur districts (SDA, 2017).

Table 1: Different Types of marble found in Pakistan (Ashmole and Motloung, 2008).
S. Types based Occurrences
No. on color

\section{Color descriptions}
1 White
$2 \quad$ Black
Muhammad Agency, Chitral, Buner, Swat, Parachinar, Gilgit, Hunza, Swabi, Malakand
3 Green
Buner, Bajour. Mardan, Bela
$4 \quad$ Pink
Nowshehra, Chitral, Lasbela
Swat, Swabi, Buner, Azad Kashmir and Lasbela, Jhuli,Zard Khan, Zeh
$5 \quad$ Grey
6 Brown
Buner, Bajour, Mar
Agency, Lasbela
Bunner, Swat, Kohat, Waziristan, Khuzdar bark brown with wh
brown fossils
$7 \quad$ Yellow
Pure white: white with pink, brown and green shades, white to grey with yellowish patches, white to light grey with yellowish brown patches, creamy white
Deep black with patches of white, black with white and golden steaks
Dark green, green with streak and patches of white grey and black, greenish white, dark green with layers of light green, green with streaks of white and yellow
Pink with streaks and patches white, grey,redand brown :pink with fossils
d Grey with white bands, grey with pink, brown and green patches 
Table 2: Major marble belts occurrences in KP, Khan (2017), GSP (2017), DGMM KP (2004).

$\begin{array}{lll}\text { S. No. } & \text { Belt } & \begin{array}{l}\text { Reserves } \\ \text { (Million tons) }\end{array} \\ 1 & \text { Reshun marble } & 1,000 \\ 2 & \text { Shoghore marble } & 1,000 \\ 3 & \text { Nowhsera Pink marble } & 100 \\ 4 & \begin{array}{l}\text { Swat and Kohistan Regions and } \\ \text { Southern part }\end{array} & 800 \\ \text { Total } & & 2,900\end{array}$

\section{Existing marble mining practices}

There exist very few systematic and proper mining techniques for extraction of regular blocks of marble throughout the marble quarries of the KP province. Majority of the mine operators use the centuries old primitive mining methods wherein high irregular faces are developed by drilling and blasting a few irregular vertical holes by using high explosives such as Wahbox. The high and hanging working faces of the quarry are made which cuts down due to its own weight. Consequently, irregular shaped blocks and boulders with blasting induced cracks produce, which limits the scope of value addition in certain highpriced products such as tabletop, flower vases and other decorative items.

As a result of this haphazard mining, many problems and challenges are faced by the marble industry of the country in general and the province of $\mathrm{KP}$ in particular to ensure smooth and safe excavation of marble blocks from the quarries. Some of them are discussed in the following sections

\section{Materials and Methods}

In this research, marble leases/areas where major activities are being carried out, were visited and data is collected from the labor, supervisors, engineers, contractors, lease holders and concerned government officials. The Minerals Department of the Government of Khyber Pakhtunkhwa facilitated the research in providing the reserves, production and accidents data, whereas the rest of the data is collected in the form of a questionnaire (Supplementary Material), by observing the field activities and interviewing the concerned people. After thoroughly analyzing the data, the following problems associated with marble industry of KP are identified.
Problems faced by the marble industry of Khyber Pakbtunkbwa

Several problems associated with dimension stone industry especially marble sector, were observed, but some of them are major sources of failure of the industry, which are discussed below.

\section{Lack of financial resources and equipment}

It is an established fact that substantial investment is needed for developing a mine as per international standards. Huge machinery such as diamond wire saw, chain saw, loader, dumpers, and excavators etc. are needed to develop a dimension stone quarry properly. The only mechanization that can be seen at the marble quarries is in the shape of handheld drills, locally fabricated winches for loading blocks (Figure 2) and compressors. Therefore, the mine operators are forced to excavate small blocks that can be handled easily with the existing machinery.

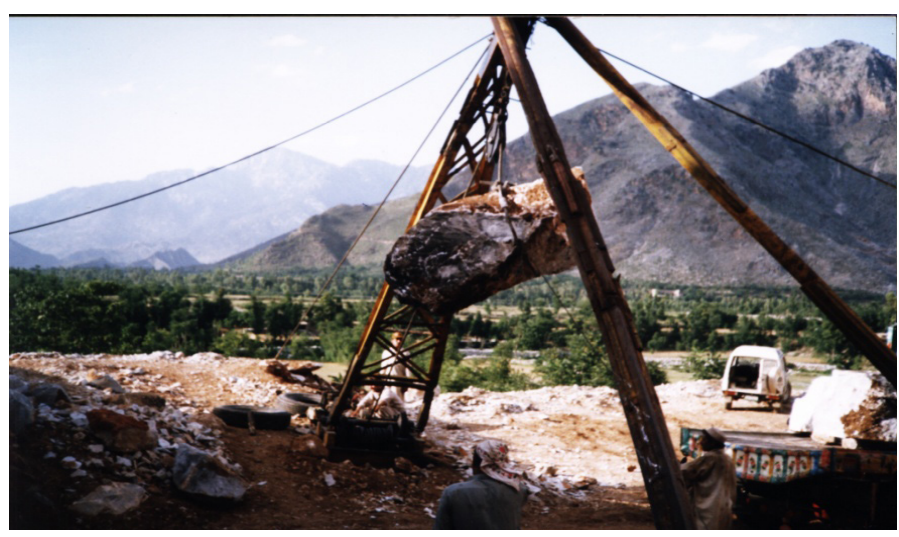

Figure 2: Blocks loading with the help of a simple winch machine used in Buner area.

Moreover, majority of the mine operators/owners of the mining sector are small scale investors with limited financial resources. They cannot afford to develop their quarries properly by stripping overburden appropriately, make suitable sized benches and acquire modern technology. Consequently, the stone extraction is started from the easily accessible locations without stripping overburden and properly handling the waste material produced (Figure 3). In these practices, some part of the reserves is extracted while an enormous portion of the deposit gets buried under waste material and become inaccessible.

\section{Waste disposal problem}

Handling and properly dumping of waste material is one of the major issues of the dimension stones mining in the province of Khyber Pakhtunkhwa. Under existing extraction techniques, significant proportion 
of excavated marble goes to waste in the form of crushed material (50-60\%) (Figure 4). Stripping outcrops and improper disposing off the wastes, is another major source of wastage. It is observed in the field visits that most of the mines are in their initial stages and working in the loose and immature portion of the deposit where prodigious quantity of minor and major cracks causes a major portion of the wastes at mines. This waste goes on accumulating at the quarry sites and causes multiple problems including higher handling costs and difficulties in further mining. Sometimes, higher percentages of wastage forces the mine operators to close further mining. For example, in District Buner in 2003, out of 225 marble leases only 47 were in operation and rest of the quarries were closed due to different reasons including overlying waste near the face (Inspectorate of Mines, KP, 2019).

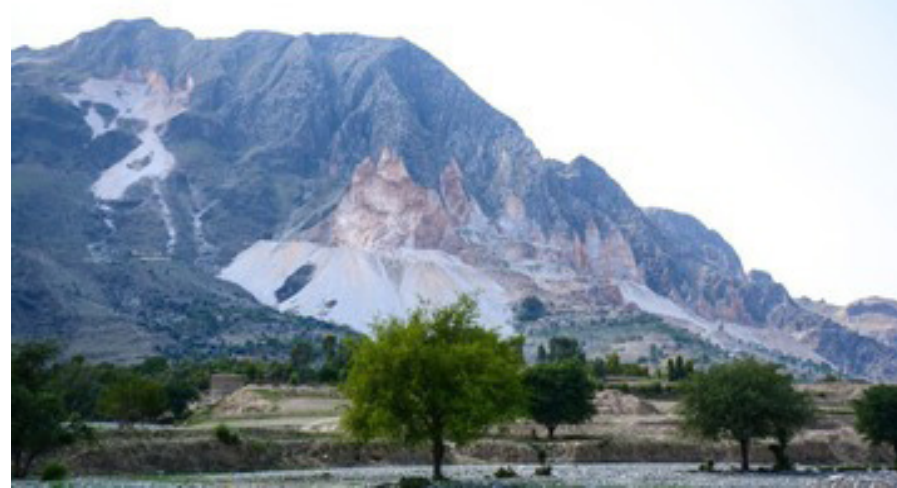

Figure 3: Marble quarry sites in Mohmand Ex-Agency (Source: Khan, 2018).

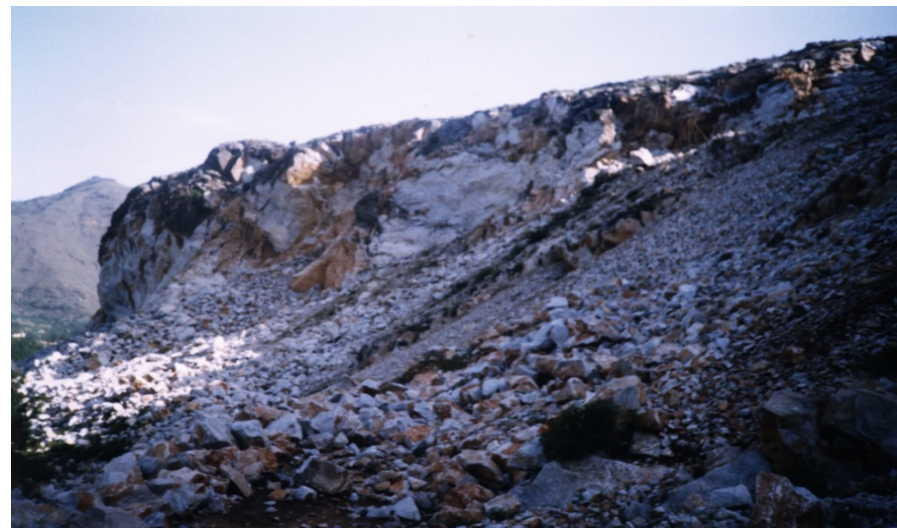

Figure 4: Five working faces were closed due to accumulation of waste on the sites in district Buner.

\section{Deficiency of infrastructure}

In the field visits, it was observed that benches and roads are not properly developed and the scale of necessary infrastructure such as electricity, colonies for the workers and transportation arrangements are not sufficient, therefore transportation costs of blocks from quarries to processing units considerably increase the production cost, which ultimately affect the market trends. Also due to inexistence of proper roads, schools, hospitals, and colonies for the workers, they hesitate to work in the mines and thus the mine operators will have to rely on the locally available limited number of labor most of them are nontechnical.

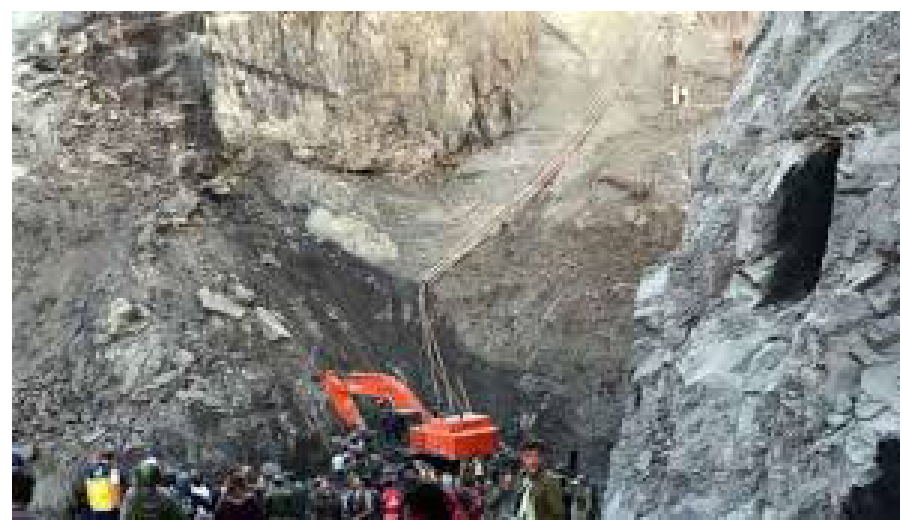

Figure 5: Accident occur due to bigh and hanging working face fall at Ziarat marble quarry, District Mubmand in September 2020.

\section{Development of high and hanging working faces}

As mentioned earlier, majority of the dimension stone quarrying is commenced from the easily accessible and near to the ground level locations where after excavating some portion of the rock remains in the form of high faces. In some quarries height of these faces reaches more than $200 \mathrm{ft}$ (Figure 5). The high faces on one hand become inaccessible for further quarrying and on the other hand are considered as most hazardous due to overhanging lose rocks which pose high risk to workers working at lower levels of quarries. Figure 6 shows data regarding accidents occurred in district Buner from 1991 to 2017 which reflect that majority of the accidents occurred due to fall/slippage of marble pieces from the high and hanging working faces (Inspectorate of Mines, KP, 2019 and field visit). According to the data collected from the Inspectorate of Mines (2019) and field visits, out of 135 accidents, 78 were due to hit by falling block/rock/boulder which is about $78 \%$ of the accidents (Figure 5). According to the data, from March 1993 to mid of 2017, 50 accidents occurred in Mardan division (Mardan and Swabi) in marble quarries except one (who was died due to heart attack) all of them were due to fall of rock/blocks on the persons. Out of these 50 accidents 44 were fatal accidents (Inspectorate of Mines, KP, 2019). In the last 3 to 4 years, due to fall of the high and hanging working faces, accidents rate increased tremendously. In February 2020, nine (9) workers died and 22 injured 
face slide accident at Bampokha, Buner. Similarly, on September 7,2020 a slide occurred at Ziarat mines in Mohmand District, where 34 workers died (Figure 5).

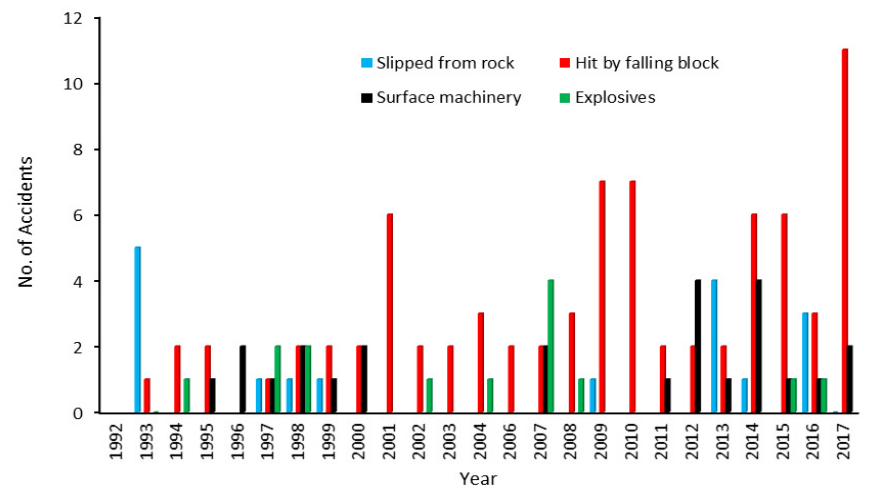

Figure 6: Summary of accidents occurred in District Buner from 1991 to 2017.

Source: Inspectorate of Mines Khyber Pakhtunkhwa (2017).

\section{Extraction of irregular shaped blocks}

Due to centuries old irregular drilling and blasting method and consequent fall of large boulders under gravity from heights, irregular shaped boulders and lumps in varying sizes produce (Figure 7). Under existing mining practices, it is extremely difficult to control over this phenomenon and hence the quality of raw marble significantly affects. Consequently, it becomes one of the major sources of waste production at mines as well as processing units (Figure 8). If by chance, a large boulder is extracted then a great problem is faced in handling the boulder with a simple winch machine or manually which is then further blasted into smaller pieces and become a source of further waste production.

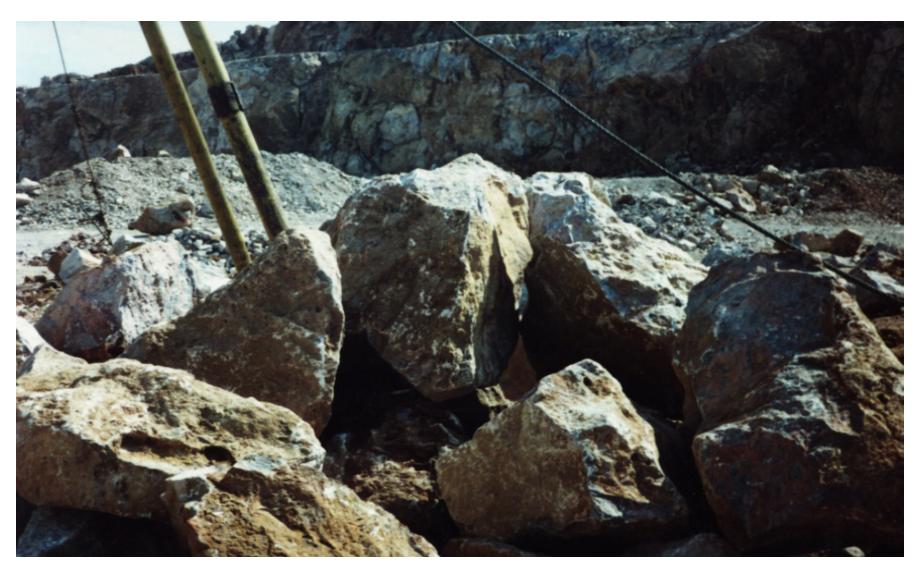

Figure 7: Irregular/potato shaped blocks (waste) produced during existing marble extraction techniques in District Nowshera.

Production of blocks with the blasting induced cracks Durability and color are major factors that affect the final prices of the dimension stones. Due to uncontrolled blasting, use of high explosives and irregular drilling patterns, many cracks and micro fissures develop both in the blocks as well as remaining faces which further reduces quality and durability of the finished products (Figure 9). The micro cracks further develop with the use of the marble tiles especially in floors.

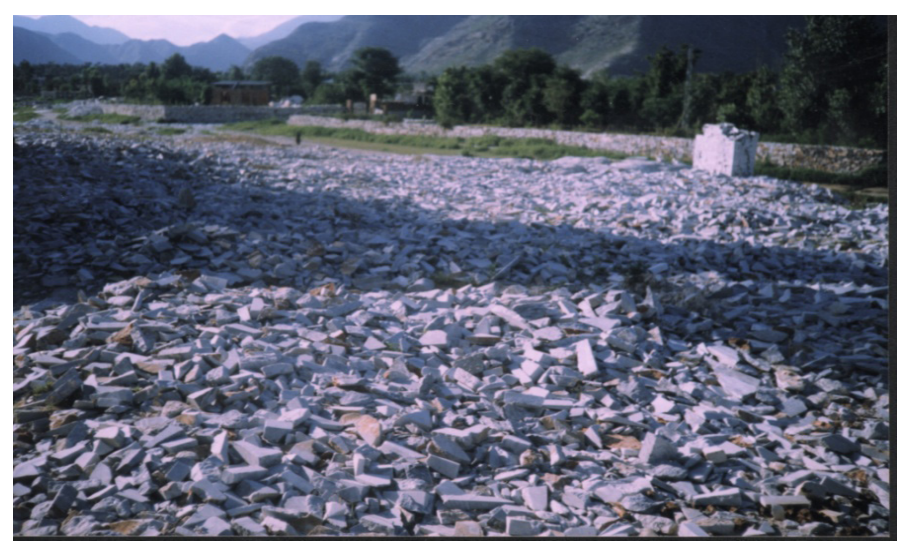

Figure 8: Waste produced as a result of marble processing in a processing unit in District Buner.

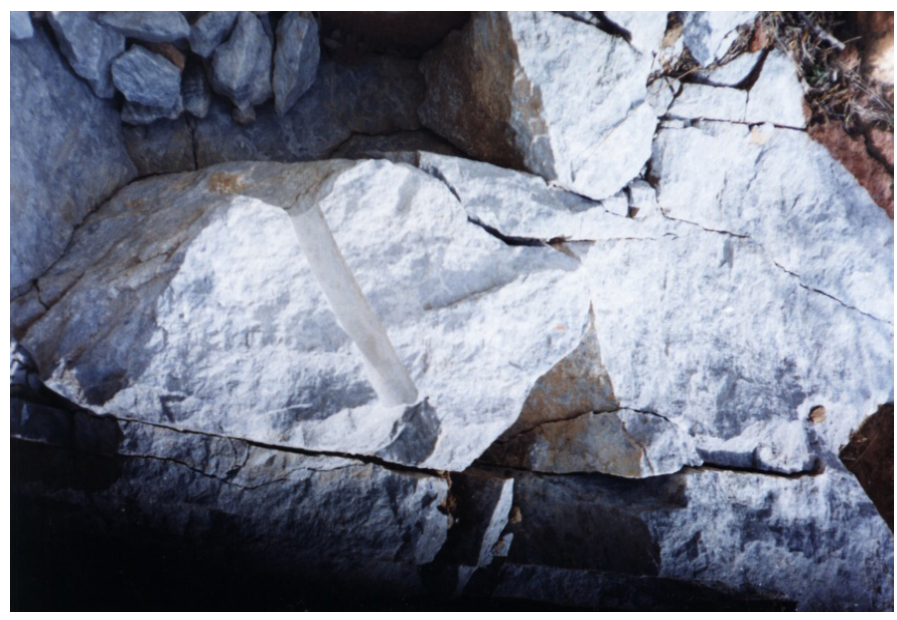

Figure 9: Cracks developed in the block due to indiscriminate blasting under the existing mining techniques in District Mardan.

\section{Deficiency of research and development work}

Research and development culture is badly lacking in the mining sector of Pakistan in general and in dimension stone sector in particular. There exists no co-ordination between Research and Development ( $\mathrm{R}$ and $\mathrm{D})$ organizations and the industry. Due to lack of interest on part of the industry in Research and Development, the pace of research in $R$ and $D$ organizations and Universities is low and is mainly carried out to meet the academic requirements. People involved in mining especially small-scale private owners are not ready to invest in the research work. They mainly rely on the concerned Government Departments for the solution of problems they face from time to time. 
China, Italy, Turkey and other developed countries have paid due attention to research and development work in the sector and thus are leading the world.

\section{Lack of skilled/trained manpower}

Technical manpower is lacking badly in the dimension stone sector of Khyber Pakhtunkhwa. It is a common problem throughout the mining sector of Pakistan. According to the survey carried out during field visits, among 311 workers, only 92 were semi-skilled such as drillers and compressor operators. They were just experienced workers and had no formal training or diploma/certificate. During field visits and data collected from the Inspectorate of Mines and Minerals (2019), out of 141 active leases of marble throughout the province there are only 15 mining engineers working permanently in the marble mines, rest of the technical manpower is drillers, blasters and winch operator, whom have got no proper training or relevant education. Apart from those 15 mining engineers, Inspectorate of Mines and Minerals send graduated students for apprenticeship of 6 months' period, but they mostly left the job before completing their tenure. Main reasons for the lack of interest of Mining Engineers to work in the marble sector are less pay, lack of facilities for engineers to stay on the sites and ruthless behavior of lease holders/contractors with the mining engineers.

Skilled and trained workforce is essential for introducing new technology and developing the dimension stone sector. Therefore, regular training of the workers and especially the technical manpower is needed from time to time, to meet the requirements of the new technological developments in this sector. So far, in our country, there is no formal institution dedicated to impart training on mining and processing of dimension stone although during field investigations, it was observed that the workers are interest in learning techniques to improve quality of their products. One of the major reasons for this deficiency could be absence of practical application of newly developed techniques in the mining sector especially in the field of dimension stone mining.

\section{Absence of mining and geological know how}

During field visits it was observed that non of the lease holders or contractors'/mine operators has got any diploma/certification or degree relevant to mining or geology. Rather, they do not know the basic terminology of geology or mining. Without appropriate geological and mining knowledge, the private sector involved in unplanned mining which in turn ruined the valuable products and shortened the lives of precious reserves.

Production based employees wages The workers are mostly paid wages based on their production of dimension stone rather than the quality of the extracted blocks. They are paid wages weather the extract regular blocks, irregular boulders, semi-blocks or Kanda. Also, there is lack of proper equipment for drilling, blasting and handling of large blocks which are difficult for the workers to handle, therefore they prefer to extract small sized blocks, which are easy in handling and consequently results in considerable wastage at quarry sites.

\section{Worth of the raw products}

While field visits it was noticed that whatever is the shape of the block, the factory (processing unit) holders pay a fixed price for the raw products based on the quality and weight of the stone produced. There is no difference in value of the raw blocks whether they supply regular or irregular blocks. This forces the mine operators to extract as much stone as possible without caring about its regularity or proper shape. This also results in improper/quick extraction of irregular shaped blocks and hence in destruction of the valuable reserves.

\section{Socio-political problems}

Socio-political problems mainly related to surface rent, disposing of waste at proper locations, political interference, boundary disputes and blasting related issues nearpopulated areasbadlyeffect the development of marble sector in Khyber Pakhtunkhwa. In Buner district, only two most productive and best quality marble quarries of white marble remained closed for about three years (2000-2003) due to conflict between lease holders and locals. As a result of this uncertainty, the leaseholders feel insecure and lose interest in investing and developing their mines on long-term basis. This sense of insecurity compels them to opt for short-term benefits and try to get maximum payback in minimum time without thinking about the future of the project. Lack of security from concerned Government Departments, especially in the tribal districts where tribal customs and laws are so strict that restrict the potential investors to invest in this sector. 
Table 3: Accident detail of Marble Mines in District Buner from 1993 to 2017.

\begin{tabular}{|c|c|c|c|c|c|c|c|c|}
\hline \multirow[t]{2}{*}{ S. No. } & \multirow[t]{2}{*}{ Year } & \multirow{2}{*}{$\begin{array}{l}\text { No. of acci- } \\
\text { dents }\end{array}$} & \multicolumn{2}{|c|}{ Nature of accident } & \multicolumn{2}{|c|}{ Cause of accidents } & \multirow[b]{2}{*}{$\begin{array}{l}\text { Surface ma- } \\
\text { chinery }\end{array}$} & \multirow[b]{2}{*}{ Explosives } \\
\hline & & & Fatal & $\begin{array}{l}\text { Serious bodily } \\
\text { injury }\end{array}$ & $\begin{array}{l}\text { Slipped from } \\
\text { rock }\end{array}$ & $\begin{array}{l}\text { Hit by fall- } \\
\text { ing block }\end{array}$ & & \\
\hline 1 & 1991 & 1 & 1 & & 1 & & & \\
\hline 2 & 1992 & & & & & & & \\
\hline 3 & 1993 & 6 & 5 & 1 & 5 & 1 & & - \\
\hline 4 & 1994 & 3 & 2 & 1 & & 2 & & 1 \\
\hline 5 & 1995 & 3 & 1 & 2 & & 2 & 1 & \\
\hline 6 & 1996 & 2 & & 2 & & & 2 & \\
\hline 7 & 1997 & 5 & 3 & 2 & 1 & 1 & 1 & 2 \\
\hline 8 & 1998 & 7 & 4 & 3 & 1 & 2 & 2 & 2 \\
\hline 9 & 1999 & 4 & 3 & 1 & 1 & 2 & 1 & \\
\hline 10 & 2000 & 4 & 3 & 1 & & 2 & 2 & \\
\hline 11 & 2001 & 6 & 5 & 1 & & 6 & & \\
\hline 12 & 2002 & 3 & 3 & & & 2 & & 1 \\
\hline 13 & 2003 & 2 & 1 & 1 & & 2 & & \\
\hline 14 & 2004 & 4 & 2 & 2 & & 3 & & 1 \\
\hline 15 & 2006 & 2 & 1 & 1 & & 2 & & \\
\hline 16 & 2007 & 8 & 8 & & & 2 & 2 & 4 \\
\hline 18 & 2008 & 4 & 4 & & & 3 & & 1 \\
\hline 19 & 2009 & 8 & 8 & & 1 & 7 & & \\
\hline 20 & 2010 & 7 & 6 & 1 & & 7 & & \\
\hline 21 & 2011 & 3 & 3 & & & 2 & 1 & \\
\hline 22 & 2012 & 6 & 6 & & & 2 & 4 & \\
\hline 23 & 2013 & 7 & 5 & 2 & 4 & 2 & 1 & \\
\hline 24 & 2014 & 11 & 7 & 4 & 1 & 6 & 4 & \\
\hline 25 & 2015 & 8 & 7 & 1 & & 6 & 1 & 1 \\
\hline 26 & 2016 & 8 & 5 & 3 & 3 & 3 & 1 & 1 \\
\hline 27 & 2017 & 13 & 11 & 2 & 0 & 11 & 2 & \\
\hline Total & & 135 & 104 & 31 & 18 & 78 & 25 & 14 \\
\hline
\end{tabular}

Source: Inspectorate of Mines, Government of KP, 2019 and field visits.

\section{Marketing issues}

The mine operators due to their limited financial resources try to sell the product as soon as possible at the quarries and avoid transportation cost and holding the stock at quarries. The processing unit owners and the middlemen takes full advantage of this and purchase the stock at reduced prices on site. The high transportation cost coupled low selling prices reduces the overall return of the mine owners. On the other hand, there is no supply and demand control system by which mining, and marketing of the stone could be regulated. Since the mine operators have less or no exposure to both local and international markets and are not aware of the prices of their products and the prices of the blocks extracted with a proper modern mechanized method which have no blasting induced cracks. As a result of this unawareness, they extract the dimension stone with the centuries old conventional (drilling and blasting) methods and then sell it at the quarry sites instead of taking it to the market.

\section{Less focus on value addition}

Major use of dimension stone in Pakistan is used in surfacing of walls and floors, there is less focus on its use for other decorative purposes. It is estimated that a cut gemstone and decorative stone fetch ten times higher prices than an uncut stone. In our country, there is lake of proper cutting and polishing facilities for dimension stones and gemstones to meet the demands of the international market.

\section{Unsafe working environment}

There is no proper safety arrangement for workers at any marble quarries, which increases the chances 
of accidents and decreases the interest of workers to work in the marble quarries. According to a record of ten years (1991-2017), collected from Inspectorate of Mines, Khyber Pakhtunkhwa and field visits (Table 3), 135 accidents occurred in District Buner in marble quarries, out of which 104 were fatal and 31 were serious bodily injuries. Among 135 accidents, 78 were hit by falling block/rock and majority of them were hit by falling stone on head or trapped in the collapsed rock. Since, the workers do not wear proper safety dress (helmet, safety shoes and proper dress), therefore majority of those hit by fallen boulders were died. Apart from that 25 accidents occurred due to machinery and again by not wearing proper safety dresses. 18 and 14 accidents occurred due to slippage from rock and blasting respectively and again by not applying proper safety measures. This statistic shows that maximum accidents occur due because of hitting or slippage of marble blocks from the high and hanging faces and unavailability of proper safety management.

Besides these, there could be other issues which restrict the development of dimension stone sector of Pakistan in general and of KP in particular. We need to highlight these hurdles and address them to flourish the dimension stone sector of the province. A mitigation plan based on the above study is presented in the following section.

\section{Mitigation plan}

For sustainable economic development of marble sector of the country, it is suggested to commence concrete efforts to explore, develop and exploit dimension stone on scientific and planned manner. For this purpose, the following recommendations will be fruitful if followed properly.

1. Lack of financial resources is one of the major hurdles in the development of marble industry of this province. The mine owners and contractors are not great investors. The Government should encourage the private sector and assist them in:

- Providing the infrastructure like, constructing roads from quarries to the processing units and markets and in building colonies for workers.

- Smooth supply of basic utilities like power and water at quarries and colonies

- Providing funds and loans from banks on soft conditions for introducing new technology in the sector

- Providing safe and appropriate atmosphere for investors in the sector to come and invest for its development.

- Importing the modern technology for extraction and processing of marble by relaxing taxes and other charges which can also encourage local manufacturers to prepare equipment through reserve engineers.

- Providing expertise by employing mining engineers, geologist, and other technical staff in marble quarries.

2. Research and Development activities in the sector should be improved. The detailed exploration, preparation of topographic and geological maps and collection of data index and geochemical properties, could play a vital role in bringing significant improvement in existing conditions.

3. Accumulation of waste during quarrying and processing must be reduced by introducing modern technology in the sector and by properly handling the wastes produced both at quarries and processing units. The mine operators should be forced to stop aaccumulation of waste at quarries to have access to further work. With this environmental protection will also be made sure.

4. To maximize gain from the export of dimension stone and win its due share in the world's market, it is important for the traders to concentrate on marketing raw, intermediate and finished products for which a high demand exists in the international market. The quality, quantity, size and uniform grade of colour needed to be maintained by processing units in order to meet the market demands.

5. The lease holders must hire technical staff to ensure efficient and safe mining operations.

6. Leases should be granted to financially and technically sound parties to develop their quarries properly with modern technology.

7. Implementation of concession rules should be ensured for smooth operations of quarries and special attention should be given to resolve disputes arise on surface rent etc.

8. To further accelerate the growth of this industry, it is essential to establish technical institute, where manpower could be trained with modern mining and processing techniques and technology.

9. Pakistan should extend its market to the potential countries. Feedback from the local architects and builders will also be helpful in ascertaining the type of stones that can be supplied to those countries. 
10. To pursue aggressive marketing approach by introducing our raw products in local and international markets. The products should be advertised through magazines, internet, international seminar/fairs, televisions, brochures and opening warehouses abroad and in Pakistan.

11. Pakistan should get expertise of China for development of marble sector as China is one of the countries where the dimension stone sector is fully equipped with modern technology and has a great contribution in the world's dimension stone production. China is preferred because it has friendly relations with Pakistan and neighbor of Pakistan. There should be a project for development of dimension sector of Pakistan in the CEPAC.

12. The lease holders/contractors should give more incentives to those workers, who will work properly and extract regular shaped blocks, while the processing unit holders should also pay more prices for regular shaped blocks which are easy to handle and yield less waste during processing.

\section{Conclusion and Recommendations}

There is a great potential of best quality marble in Pakistan, especially in the province of Khyber Pakhtunkhwa but there are a number of difficulties which impede the development of this sector and hence the final product of marble could not meet the international standards, it has less value and could not compete in the international market. In the research documented here, problems which the marble industry of Khyber Pakhtunkhwa (KP) faces are observed and investigated. After thorough analyzes of these issues, it was discovered that lack of financial resources, accumulation of wastage at quarry sites, unavailability of skilled manpower, production of irregular shaped blocks, production of blasting induced fissures and micro cracks, socio-political problems and lack of research and development activities are some of the major issues which the industry faces.

To minimize the impact of these problems on the marble industry of the country as well as of the province, the Government of Pakistan should assist this sector in providing infrastructure, funds, safe and appropriate environment for investors, modern technology, expertise, creating research and development environment and in implementing proper procedures for marble extraction. The Government should also extend its dimension stone market internationally and should seek technological and financial help from other countries especially from China. On the other hand, the lease holders/mine owners should facilitate and support research in the marble sector, develop their quarries according to the required standards, dump wastage appropriately, hire technical workforce, avoid centuries old uncontrolled blasting techniques and provide better environment for the workers so that their quarries production and recovery could be increased. Detailed recommendations are already presented in the mitigation plan.

\section{Novelty Statement}

This article shows the real time issues which the marble sector of Khyber Pakhtunkhwa faces. These issues are not highlighted and mitigation plane for the marble sector has not been witnessed in any other literature.

\section{Author's Contribution}

Salim Raza has completed the research and prepared the initial draft of the manuscript.

Khan Gul Jadoon has supervised the research and facilitated the research in arranging transport and financial assistance.

Sajjad Hussain, Zahid ur Rehman and Saira Sherin assisted the research in collecting data and editing the manuscript.

\section{Supplementary Material}

There is supplementary material associated with this article. Access the material online at: http://dx.doi. org/10.17582/journal.jeas/39.1.77.86

\section{Conflict of interest}

The authors have declared no conflict of interest.

\section{References}

Ashmole, M. and Motloung. 2008. Dimension stone: The latest trends in exploration and production technology. Southern Africa: The Southern African Institute of Mining and Metallurgy.

Directorate General of Mines and Minerals (DGMM), Khyber Pakhtunkhwa, 2004. Dimension stone reserves of the province. 
GDM Stone Industry Handbook, 2000. Marble and More. Downloaded from http://www. minerlszone.com in 2003.

Geological Survey of Pakistan (GSP), Report (2004 and 2017).

Inspectorate of Mines, Government of Khyber Pakhtunkhwa, 2019. Detail of dimension stone reserves, mining and accidents of Khyber Pakhtunkhwa.

Khan, A., 2018. In photos: Marble quarry in Mohmand agency. Downloaded on $26^{\text {th }}$ April 2019, from website of Pakistan Forward: http://pakistan.asia-news.com/?locale=en_ GBandnav=true

Khan, T.A., 2017. Word press an endeavour for tolerance, peace and development. Retrieved downloaded from https://tahirkatlang. wordpress.com/20 10/06/25/marble-resourcesin-Pakistan/

Merke, G., 2000. Sustainable development in the natural stone industry. Roc. Maquina.,

Mines and Minerals Development, Balochistan,

1999. Mineral reserves in Balochistan.

Downloaded from https://www.balochistan. gov.pk/images/minespdf/Mineral $\% 20$ Reserves\%20in\%20B1n\%20DGMM.pdf on 14-05-2019.

Rathore, S.S. and S. Bhandari. 2003. Prevention of damages to remaining rock while blasting in dimensional stones. $2^{\text {nd }}$ international conference and exhibition (STONEMART 2003), held at Jaipur, India, Jan. 31 to Feb. 4, pp. 114-120

Rehman, Z., S. Hussain, N. Mohammad, S. Raza, S. Sherin, M. Khan, M. Tahir and M. Khan. 2018. Comparative analysis of different techniques used for dimension stone mining. J. Himal. Earth Sci., 51(1): 23-33. https://doi. org/10.1155/2018/7159873

Sarhad Development Authority (SDA), 2017. Minerals development section.

U.S. Geological Survey, 2018. Mineral commodity summaries 2018: U.S. Geological Survey, pp.156. 